\title{
Are Smaller Cities More Sustainable? Environmental Externalities in Urban Areas. Evidences from Cities in São Paulo, Brazil
}

\author{
Priscila B. Santiago, Jorge M. Nogueira*, Pedro H. Z. da Conceição \\ Department of Economics, University of Brasilia, Brasilia (DF), Brazil \\ Email: priscilasantiago@cnt.org.br, ${ }^{*}$ imn0702@unb.br, pedrozuchi@unb.br
}

Received 23 September 2014; revised 28 October 2014; accepted 5 December 2014

Copyright (C) 2014 by authors and Scientific Research Publishing Inc.

This work is licensed under the Creative Commons Attribution International License (CC BY). http://creativecommons.org/licenses/by/4.0/

c) (7)

\section{Abstract}

The objective of this essay is to explore the relationship between economics of agglomeration, city sizes and negative environmental externalities. Therefore, we contribute to illuminating the controversy on optimal city size, which has been much more concentrated on the reality of developed nations. We emphasize environmental dimensions related to this debate focusing on developing country urban agglomerations. In order to do so we test the hypothesis that smaller cities present better environmental quality indicators than bigger urban centers. Our tentative of rejecting this hypothesis was based upon data on more than 600 cities in the state of São Paulo, Brazil, including its capital city of São Paulo, one of the largest cities in the world with more than 12 million inhabitants. We used cluster technique for a multivariable analysis with several environmental indicators-for water quality and for solid waste disposal and management-and an aggregated quality of life indicator very similar to the Human Development Indicator (HDI). Our results reject the hypothesis that smaller cities in a developing country reality are more environmentally sustainable than bigger cities.

\section{Keywords}

Environmental Externalities, City Sizes, Economics of Agglomeration, Environmental Economics

\section{Initial Comments}

The world population is increasingly urban and lives in large cities. Data from the United Nations Program for Urban Settlements show that the growth rate of world's urban population is $1.8 \%$ per year, while the rural popu-

\footnotetext{
"Corresponding author.
}

How to cite this paper: Santiago, P. B., Nogueira, J. M., \& da Conceição, P. H. Z. (2014). Are Smaller Cities More Sustainable? Environmental Externalities in Urban Areas. Evidences from Cities in São Paulo, Brazil. Current Urban Studies, 2, 323-334. http://dx.doi.org/10.4236/cus.2014.24031 
lation has grown only $0.1 \%$ p.a. (UN-HABITAT, 2005). In a global scale, the urban population will grow from 3.6 billion people in 2011 to about 6.3 billion in $2050^{1}$, with the vast majority living in cities of low and middle-income countries. Increases in population density and intensification of the economic activities in urban areas generate positive effects upon human well-being: expansion of employment opportunities, increase in productivity and in income. Nonetheless, higher population density and production concentration also generate undesirable effects upon human well-being and reduction in the quality of urban environment: congestion and air pollution, for example. Nevertheless, these are not the only negative effects of urban crowding.

Expansion of urban areas and increase of population density in these spaces demand the choice of better strategies for the development and management of urban agglomerations. Economic analyses argue that the size of a city is directly related to the availability of human, financial and economic resources. At the same time, urban economics reasoning suggests that as cities grow benefits of agglomeration decrease and its negative effects increase rapidly. However, recent studies, as the one developed by Au and Henderson (2006) for North American and Asian cities, suggest that big cities are best suitable to the promotion of environmental conservation. The argument is based upon the fact that such cities, due to higher concentration of income, have for more resources available for dealing with environmental issues.

It is worthwhile to emphasize that the arguments by Au and Henderson (2006) go against a widespread belief among policymakers and managers that smaller towns are better suited to maintain the environmental quality of urban areas. For many of these analysts, big cities are not desirable from an environmental perspective. In their opinion, the spatial organization of large urban centers is the worst possible option for sustainability due to various negative externalities derived from the gigantic size of some cities: congestion, air pollution, intolerable noise levels, reduced green areas, to mention only a few.

The controversy between those in favor of large city advantages and those who postulates greater environmental sustainability of smaller urban centers is far from being resolved. Spatial and environmental analyses are not among the most popular research theme among economists. Both areas of investigation tend to motivate more other scientists in geography, agriculture, biology, engineering and architecture. Hotelling (1929) was probably a pioneer in introducing the spatial variable into economic analyses. However, even when considering the spatial dimension, economists tend to incorporate it in dealing with issues related to industry location, energy, telecommunications and transportation.

Observers of urban development and environmental issues, Gaigne, Riou and Thisse (2011) developed the study “Are compact cities environmentally friendly?”. In so doing, they used the transportation system to measure environmental and financial costs of large and small cities. The transportation system was chosen because the movement of people and commodities is responsible for about $30 \%$ of the total emission of greenhouse gases. In addition, from this emission $80 \%$ come from private cars. Whereas energy efficiency is not enough to solve problems of pollution and of environmental damage, these authors advocate the reduction of covered distances reduces the emission of gases. They conclude that large and polycentric cities are more environmentally efficient than compact cities.

Motivated by the research of Gaigne, Riou and Thisse (2011), this paper sets out to test the hypothesis that compact cities provide better environmental quality than major urban centers. However, unlike Gaigne, Riou and Thisse (2011) we take into consideration other environmental impacts related to urban areas besides the usual air pollution. It is our understanding that the use of more diversifies set of environmental indicators is more suited to illuminate the controversy highlighted above. A broad set of indicators enables broader and easily understood analyses.

Due to the lack of data for Brazil as a whole as well as the low reliability of existing data, we have decided to test our hypothesis only to the cities in the state of São Paulo, the economic powerhouse of the Brazilian economy. In this context, the question to be answered is: do smaller cities have more environmental benefits than large? In order to answer it, we use cluster multivariate analysis and factorial analysis in order to identify the relationship between size of cities and level of environmental quality reflected on those selected variables. This is done by means of a comparison between large and small municipalities with regard to environmental quality.

This paper has four sections besides this introduction and a conclusion. Section 2 presents a review of the literature on the existence of urban agglomerations, its origins, benefits and harms, as well as highlight the great correlation between the spatial and environmental studies. Section 3 presents, in turn, the object of study: municipalities in the state of São Paulo, the selected environmental indicators, as well as data sources and methodo-

\footnotetext{
1“World Urbanization Prospects, the 2011 Revision” available in http://esa.un.org/unpd/wup/index.html, accessed in March 10, 2013.
} 
logical procedures (cluster and factorial analyses) followed in order to develop our analysis of environmental indicators of the municipalities. Finally, Section 4 describes our results derived from the developed analyses. Special attention is given to both techniques employed and to the difficulties encountered in each one of our simulations.

\section{Cities, Economies of Agglomeration, Externalities and the Environment}

Urban agglomerations are nothing more than the spatial concentration of economic activities. They occur because of increasing returns to scale, known as agglomeration economies. The existence of cities has become a global phenomenon as they speed up the economic development of societies (Fujita \& Thisse, 1996 and 2002). In fact, the spatial agglomeration of economic activity and economic growth are difficult to separate. It is clear that the process of urban concentration is not new, but its intensification in recent years is impressive (Rosenthal \& Strange, 2004). Studies estimate that in 1800 the world urban population concentrated in cities with more than 100,000 inhabitants was less than $2 \%$ of the total. In 1850 , the proportion would have passed to $2.3 \%$, in 1900 , to $5.5 \%$. Furthermore, data from the World Bank claim that currently more than $50 \%$ of the world's population is urban (Banco Mundial, 1992, 2009 a and b).

Lampard (1955) argued many years ago that it is hard to make a generalization about the origin and history of cities. This difficulty is due to the fact that cities vary according to time, function and location. Nevertheless, it is possible to identify some points that characterize life in cities: increased economic efficiency, optimization of working conditions, public services and market access. Cities produce a basket of goods that is not possible to be produced in isolated areas. As presented by Mills (apud Henderson, 1972 and 1974), even the simplest city is able to produce goods for domestic consumption and export, housing and transportation. Thus, the clustering in cities would occur due to economies of scale. These would be from both the reduction in production costs (transportation, raw materials, skilled labor, public services) and due to the existence of a large captive market.

According to Thisse (2002 and 2011) there is consensus that the economics of space can be considered as the product of trade-offs between different types of economies of scale in production and the cost of mobility of goods, people and information. Although been repeatedly rediscovered, this trade-off is at the heart of economic geography since the work of the first location theorists. This suggests that the location of economic activities is the result of a complicated balance of forces that pull and push consumers and businesses in opposite directions.

There are, in fact, various types of economies of scale, which would not exist in isolation. Agglomeration generates favorable situations for all actors involved (Verhoef, \& Nijkamp, 2003). One of the main arguments in the debate about the urbanization is focused on whether quantity and quality of services demanded or supplied for the urban population are higher than they were on less urbanized regions when compared in terms of income. Income elasticity of demand for public goods is positive and higher in areas that have a higher degree of urbanization. This positive income elasticity reflects the willingness to pay taxes and contributions that may finance the provision of the services (Linn, 1982).

Cities, especially larger ones, offer several advantages for firms. They also offer facilities to citizens, such as housing, health and education services, and markets. Therefore, according to Lampard (1955), cities become the rational choice of economic agents. Although cities present several advantages (forces of attraction or centripetal forces), they also have several factors of expulsion (centrifugal forces, Verhoef \&Nijkamp, 2003). These dispersion forces are as important as those of agglomeration in determining size and efficiency of a urban agglomeration.

It is clear, population density brings with it inherent problems. Among them congestion, environmental damage, as well as social issues - slums and ghettos - that end up aggravating the problems of urban communities (Banco Mundial, 2009). Increased demand for homes makes the rent charged increased (Glaeser \& Gyourko, 2007). Edward Glaeser (2007) presents a series of studies on the increased bid of land in cities. According to the study, is that the price of homes reflects the increased income and economies of agglomeration. Rosenthal and Strange (2001) state that the prices of homes are more related to the provision of public services (health, education and leisure) than with the proximity of urban centers. In American cities the poorest population is concentrated in the central areas, while the richest are in outlying areas (suburbs). For Glaeser et al. (2005), this distribution is related to quality and costs of transportation, besides the income elasticity of demand for land.

In a setting like this, the poorest population makes use of public transport because of its lower cost and tends to live closer to their workplace. Already the highest-income people have cars and live in more remote regions with greater space. This leads another diseconomy: urban congestion. Congestion in urban areas affect the cost 
of firms and the well-being of families. They are a kind of obstacle to trade, because they restrict access to market goods and services, increasing their costs. For Himanen, Perrels and Lee-Gosselin (2005) congestion are not something new, but currently are enhanced by accelerated growth of income in urban agglomerations and consumer-focused policies that discourage the use of public transport by the high-income population. The use of private transport to offsets commuting is inefficient. Despite the time spent on the road, buses are the most efficient vehicles, considering the volume of passengers transported and occupation of road space ${ }^{2}$.

Intensification of trade, increase production of goods and more automobiles tend to worsen air quality with consequences upon the health of those living in big cities (Banister, 1999). Despite the great attention given by researchers to the effects of urban air pollution upon the health of urban center inhabitants, human health is also affected by other negative externalities of urban agglomeration.

Among these negative externalities, inadequate management of solid waste, deficiency in basic sanitation and improper use of land sites are factors that encourage soil and water contamination. These negative externalities of urban agglomeration are widespread in cities of developing countries. As we will show later on in this paper, they are perceived in major Brazilian cities. However, these externalities and their consequences have received less attention from scholars, in spite of the fact they probably are probably the most common form of malfunctions of markets in these peripheral societies.

It is widely perceived that to the extent that cities become bigger, marginal benefits of agglomeration tend to decrease as diseconomies generated by large cities grow quickly. Eventually, a city becomes overly large so that the diseconomies exceed benefits of scale. In some cases, activities may be motivated to transfer to other locations (Wheeler, 2002). Nevertheless, as private and social costs of agglomeration are not equal, cities may operate at scales above the optimal. Nijkamp (1999) says that geographic space and environment are like twins; what happens to one, affects the other. The most noticeable relationship between environment and space are (positive or negative) externalities. In fact, one can say that externalities are the materialization of spillovers. All space-related activities—-housing, transport, industrial development, etc. are (positive or negatively) connected to environmental changes.

In relation to these aspects, Nijkamp (1999) observes that there are direct relationships between the environment and the geographic space. In special, he emphasizes:

1) space is the physical market of environmental externalities; this relationship is valid for local issues (soil pollution) and for global issues (greenhouse gas emissions);

2) space is naturally heterogeneous, so the environmental externalities resulting from its occupation are also unevenly distributed; and

3) space and the environment are scarce resources; furthermore, to use one implies the consumption of the other (complementary goods); thus, the conservation of one requires good management of the other.

One attempt to establish possible analytical links between geographic space and the environment is the debate on the optimal size of the city, as evidenced in the study by Riou and Thiesse (2011). They argue that when we think that the structure of cities can be either monocentric or polycentric, it becomes evident possible links between environmental performance and population density. Changes in population density affect income and wages; due to these effects, workers and firms may be encouraged to reallocate resources in a new standard of agglomeration. Thus, policies for encouraging decentralization of cities would be efficient as it would reduce pollution and increase the social welfare. This would be also valid for decentralization within the city itself, with the creation of poles.

Riou and Thiesse (2011) claim that the problem of the traditional analyses made on the optimum size of cities is that the models have two substantial failures. First, location of firms and individuals is thought as an exogenous variable; in fact, it is endogenous and determined by prices, wages and returns determined by the market. Second, analyses are done for cities individually without considering the spatial mobility of the factors of production. Taking into account these two factors, they defend the idea that polycentric cities are more efficient from an environmental point of view compared with compact cities.

It is not difficult to observe that the main novelty in this study is the article's analytical assumption of mobility of factors. Thiesse and Riou seek to show the effect of an increase of population density upon the environment when both firms and workers can move freely between towns (or within a polycentric city). Their analysis was used to develop a transport system to get a measurement of environmental and financial cost of large and

${ }^{2}$ While cars occupy $60 \%$ of the road space and carry $20 \%$ of passengers, buses occupy $25 \%$ of the road space and carrying $70 \%$ of passengers (CNT, 2012). 
small cities. The transport used in locomotion is seen as one of the great market failures and dead-weight loss to society.

The analysis considers the existence of a trade-off: on one side, the agglomeration reduces pollution by transporting goods between cities. On the other hand, the crowding increases the pollution by increasing distance for displacement of people to their work. The two are affected by population density and by the income level of agglomerations which are influenced by the agglomeration effect. The model presented is considered: two cities, mobility of factors, three primary goods (work, land and cash), distance between cities (or centers) and an industry. The result by the authors was that large and polycentric cities are more "green" than compact cities.

These results by Thiesse and Riou are quite unique among studies that predominantly argue that "small (city) is beautiful" from an environmental point of view. Their findings also motivated our research in a different setting. Will their results be valid for cities located in countries with lower average per capita income? Are large cities also the greenest in developing or emerging countries? What would happen to those results if other environmental characteristics, as well as air pollution, were considered in the comparison of sustainability between large and small cities? In the next pages of this paper, these questions are answered with empirical evidence for cities of different sizes in the state of São Paulo, Brazil.

\section{Cities of Different Sizes and Sustainability: Methods and Procedures}

Do smaller cities have more environmental benefits than large ones? Our main objective is to answer this question. We develop a multi-criteria analysis to see if residents of larger municipalities have lower environmental quality than the one observed in smaller municipalities. As object of analysis was selected the state of São Pau$l^{3}$, the economic richest state in the whole Brazil. The choice of São Paulo was not random, but rather guided by the availability of environmental data provided by the São Paulo State Environmental Agency (CETESB), besides the economic importance of this state to Brazil (Governo do Estado de São Paulo, 2012).

In this research we used both quality-of-life indicators and environmental indicators. Environmental indicators reveals, in qualitative and quantitative manner, the result of certain human actions upon the environment (externalities). Quality-of-life indicators reveals the utility gain of families. Among our indicators, 4 (four) are descriptive, 2 (two) are performance indicators, 2 (two) reveals efficiency and 1 (one) is a welfare indicator. In a more detailed fashion we have:

1) proportion of households with sewage collection network: measures the supply of sanitary sewage collection service in response to increase in population in cities. It is a public service and essential for the population health. This indicator varies between zero and one and it is the ratio of number of households serviced by sewage collection service and the total number of residences in the city. The distance between the observed value and 1 represents the proportion of households that still have sanitary septic tanks or riverbeds as the final disposal of their waste. Data for this indicator are from the Brazilian Institute of Geography and Statistics (IBGE) and collected from the 2010 Census;

2) sewage treatment as a proportion of sewage collected: this indicator measures the proportion of the waste collected by the sewage network that is properly treated before returned to the environment. The sewage treatment service is a public service that aims to guarantee both public health and sound management of environmental resources, mainly to avoid contamination of water and soil. The indicator, which varies between zero and 1 , is the ratio of the volume of treated sewage in relation to sewage collected by sanitary sewage network. The distance between the observed value and 1 represents the proportion of residues returned to the environment without proper treatment. The data presented for this indicator are from CETESB and available in the Groundwater Quality Report 2009;

3) proportion of households serviced by piped water delivery by distribution network: the indicator measures the supply of tap water service to the residents and businesses of the town. As an indicator of response it reflects measures taken by the Government in order to supply quality water, which has positive effects upon population health. This indicator also varies between zero and one and it is estimated as the ratio of number of households

\footnotetext{
${ }^{3}$ The State of São Paulo is located in the southeastern region of Brazil, has 248 thousand $\mathrm{km}^{2}$ and 41.2 million inhabitants. The gross domestic product (GDP) of the state is the largest in the country and, in 2009, represented more than 30\% of the Brazilian GDP. The state economy is shared among agribusiness production (6.5\%), industry (46.3\%) and services (47.2\%). The population is mostly urban (84\%) and with annual per capita GDP of \$ 26 thousand "reais" (US\$ 13 mil) is considered the richest state in the country. The state is divided administratively into 645 municipalities. The largest municipality in terms of population is the capital city of São Paulo, but in relation to geographical area is Iguapé, with $1981 \mathrm{~km}^{2}$ and 28 thousand inhabitants.
} 
served by piped treated water and service by the total number of residences in the city. The distance between the observed value and 1 represents the proportion of households that still have lakes or rivers as direct source of water for survival and economic activities. The data for this indicator are from the Brazilian Institute of Geography and Statistics (IBGE) and collected though the 2010 Census (IBGE, 2012);

4) proportion of households serviced by regular solid waste collection: this indicator measures the proportion of households serviced by regular garbage collection. It is worth mentioning that it does not reveal the periodicity of collection, but only its existence. This service also has positive effects upon population health. The indicator, which varies between zero and one, is the ratio of number of households served by regular solid waste collection and the total number of residences. The distance between the observed value and 1 represents the proportion of households that are not served by urban cleaning service and that, therefore, give various destinations to their waste. The data presented for this indicator are from the IBGE and collected in the 2010 Census;

5) number of contaminated areas: this indicator quantifies the number of contaminated areas by different sources (industry, trade, gas station-major contaminator-, waste, accidents, agriculture). It reveals inappropriate use and mismanagement of land sites. The indicator, however, only highlights the existence of a contaminated area and the source of its contamination. The extent of the area nor the severity of the contamination are not identified. Thus, it is not possible to show the extent of areas contaminated in relation to the geographic area of the municipality. From the total of registered areas were subtracted those areas already recovered. The data presented for this indicator are from CETESB and released/updated on the website of the institution where it is also possible to monitor the stage of the research process and restoration of environmental damage caused.

6) quality index of landfill waste $(I Q R)$ : the index, prepared by CETESB for all municipalities via application of a standard questionnaire, aims to assess the quality of the treatment and final disposal of solid waste produced by inhabitants and collected by the system of urban cleaning of each municipality. Varying in a range of zero to ten, the index ranks the solid waste treatment facilities or waste final disposal from inadequate to adequate;

7) daily production of garbage: measuring the tonnage of garbage produced daily in the towns; it reveals the impact of final consumption upon the environment. The indicator is expressed in absolute terms, that is, the total tons produced each day in each of the municipalities. Therefore its estimates are influenced by two basic characteristics: the size of the municipality and the income level (which directly influences consumption). The data are computed and published by CETESB in the State Inventory of Household Solid Waste and does not take into consideration the generation of waste by productive activities;

8) daily per capita garbage production: it is a variation from the previous indicator that no longer configures as an absolute, but rather as a relative, indicator. It is the ratio between the daily production of waste and the total population of the municipality. The data are sourced from the IBGE (population) and CETESB (waste);

9) Municipal Development Index (IFDM Firjan): it is prepared and released by the FIRJAN (Federation of Industries of the State of Rio de Janeiro). The IFDM is an annual monitoring of 5564 Brazilian municipalities. Three areas of human well-being are considered in IFDM: economic (employment and income), education and health. The IFDM varies from 0 to 1 . The closer to 1 , the greater the level of “development” of the locality. The IFDM was chosen because it is an indicator of quality of life that is very similar to the HDI (Human Development Index) and in addition to presenting county data, the indicator has annual periodicity.

Using these indicators we developed a multivariate analysis. Our data basis was valid for 607 municipalities in the state of São Paulo in Brazil. Given the complexity of the analysis were used two methods of multivariate analysis: cluster analysis and factorial analysis. It is well known that cluster analysis groups objects considering their similarities and differences. The formation of clusters ensures that the objects inside are the most homogeneous possible and, on the outside, the more heterogeneous as possible. The method does not distinguish between dependent and independent variables since the goal is to characterize the groups (Malhotra, 2006). This kind of analysis is particularly effective when the number of observations is large. In this way, cluster-groups are created that make the data more malleable for analyses (Cluster Analysis, Chapter 23).

The cluster formation process has basically two steps: the estimation of similarity measures and the adoption of a technique for definition the number of groups. Second Bussab (1990 apud Albuquerque, 2005) there are a number of measures of similarity being that the choice of which to use depends on the convenience of the researcher. For this work we decided to use a non-hierarchical analysis. In fact, hierarchical methodology was tested, but this was unsatisfactory to the object of study. Thus, for the analysis in question has used the k-means clustering method. For the definition of the number of clusters formed was used as auxiliary, the method vfold.

Factorial analysis is a technique that involves an examination of the interrelationships between variables, so 
that they can be conveniently described by basic categories, called factors. In so doing, one explains the covariance between variables using a statistical model and assuming the existence of $\mathbf{n}$ non-observable variables (KINGS, 1997 apud VICINI, 2005). The application of this technique allows the construction of an array of factorials which is able to explain the correlation that exists between the common factors. To do this, you use the correlation matrix of the initial indicators of the model that is being studied. Associated with the correlation matrix of indicators there are auto-vectors that provide the percentage of variance explained by factors in such a way that the sum of the variances of the factors is equal to the total variance of the model ${ }^{4}$.

Factorial analysis was used to make the construction of a Municipal-IQM quality indicator. To this end, we used the methodology developed by Smith (1999). The IQM calculated from the factorials loads aims to summarize the information about environmental quality and quality of life for each of the studied municipal districts (607). The indicator was calculated as follows:

$$
\operatorname{IQM}_{i}=\sum_{j=1}^{k} \frac{\lambda j}{\operatorname{tr}(r)} F j i
$$

where:

$I Q M_{i}$ : quality index for county $i$;

$\lambda j: j$-th characteristic root of the correlation matrix;

$k$ : number of factors;

$F_{j i}$ : factorial load of municipality i; and

$\operatorname{tr}(r)$ : trace of the correlation matrix.

After the creation of the IQM we did its normalization to facilitate comparison between the municipalities so that there were no negative values. As a result, to answer the question proposed, a new cluster analysis was developed with the results obtained with the creation of the IQM. It was, again, the k-means technique in order to group the municipalities to provide the same quality standard municipal environmental and socioeconomic elements when considered.

\section{Small Is Not Always Beautiful: The Sustainable City May Be Big}

\subsection{Cluster Analysis-Results and Analyses}

In the cluster analysis we considered the data entries for the selected variables for all 607 municipalities of the state of São Paulo. The vfold test indicated that the number of clusters best suited for data analysis would be five (5). After the definition of the number of clusters, cluster analysis, based on k-means method, was performed. Table 1 summarizes results with the characterization of clusters formed and presentation of averages-centroidvariable for each cluster under analysis. In Table 1 we also highlighted the best result for each of the nine variables considered in the analysis.

Examining Table 1 we observe a heterogeneous distribution of best environmental practices within the state of São Paulo. One cannot combine in a single cluster all the best environmental quality conditions. Nevertheless, in evaluating the characteristics of each cluster for each variable, the composition of each grouping can be analyzed and this allow us to have a proper picture of the relationship between geographical and demographic size and environmental quality.

Thus, Cluster 1 is formed by 134 municipalities and represents $22.08 \%$ of them. It has a total area of 50 thousand $\mathrm{km}^{2}$ and a total population is of 1.19 million inhabitants. Therefore, its average population density is 26.15 inhabitants per $\mathrm{km}^{2}$. Each municipality has on average a population of 39 thousand inhabitants; thus, there is a concentration of small municipalities in Cluster 1: less than 50 thousand inhabitants. The municipality with the largest population (São Roque) has 79 thousand inhabitants and the smallest (Nova Castilho), 1125 inhabitants. In terms of geographical area, the largest municipality has $1556 \mathrm{~km}^{2}$ (Teodoro Sampaio) and the smaller, $34 \mathrm{~km}^{2}$ (Nova Guataporanga). The average per capita income for Cluster 1 is $\mathrm{R} \$ 552.00$, being the highest $\mathrm{R} \$ 916.00$ (Julio Mesquita) and the smallest R 289.00 (Irapuã).

Cluster 2 has $18.29 \%$ of all municipalities (111) in a total area of $348 \mathrm{~km}^{2}$. The smallest municipality occupies $3.64 \mathrm{~km}^{2}$ (Águas de São Pedro) and the largest, $1482 \mathrm{~km}^{2}$ (Botucatu). In terms of population,the county of Guarulhos is exceptional: despite having only $318 \mathrm{~km}^{2}$, it registers 1.2 million inhabitants. The average per capita income in Cluster 2 is $\mathrm{R} \$$ 615.00; varying from R $\$ 1613.00$ (São Caetano do Sul) to R 415.00 (Potim).

${ }^{4}$ All statistical procedures were developed with the software STATISTICA 8 and Excel. 
Table 1. Results of the cluster analyses.

\begin{tabular}{|c|c|c|c|c|c|c|c|c|c|c|c|}
\hline \multicolumn{12}{|c|}{ Test results: average of the variables for each cluster, number of cases and participation of each cluster in the sample } \\
\hline & $\begin{array}{l}\text { Proportion of } \\
\text { households } \\
\text { served by } \\
\text { sanitary } \\
\text { sewage } \\
\text { network-coll } \\
\text { ection (\%) }\end{array}$ & $\begin{array}{l}\text { Sewage } \\
\text { treatment } \\
\text { as a } \\
\text { proportion } \\
\text { of the } \\
\text { collected } \\
\text { sewer (\%) }\end{array}$ & $\begin{array}{l}\text { Proportion } \\
\text { of } \\
\text { households } \\
\text { served tap } \\
\text { water (\%) }\end{array}$ & $\begin{array}{l}\text { Proportion of } \\
\text { households } \\
\text { serviced by } \\
\text { regular } \\
\text { collection of } \\
\text { solid waste (\%) }\end{array}$ & $\begin{array}{c}\text { Number of } \\
\text { contaminated } \\
\text { areas }\end{array}$ & $\mathrm{IQF}$ & $\begin{array}{l}\text { Daily } \\
\text { production } \\
\text { of waste } \\
\text { (t/day) }\end{array}$ & $\begin{array}{l}\text { Daily per } \\
\text { capita } \\
\text { garbage } \\
\text { production } \\
\text { (kg/inhab/day) }\end{array}$ & IFDM & $\begin{array}{l}\text { Number } \\
\text { of cases }\end{array}$ & $\begin{array}{c}\text { Percentage } \\
\text { (\%) }\end{array}$ \\
\hline Cluster 1 & 0.84 & 0.82 & 0.80 & 0.86 & 0.42 & 8.28 & 2.78 & 0.31 & 0.72 & 134 & 22.08 \\
\hline Cluster 2 & 0.83 & 0.46 & 0.93 & 0.98 & 10.31 & 8.89 & 68.96 & 0.44 & 0.81 & 111 & 18.29 \\
\hline Cluster 3 & 0.86 & 0.74 & 0.92 & 0.95 & 10.23 & 8.28 & 62.47 & 0.41 & 0.78 & 183 & 30.15 \\
\hline Cluster 4 & 0.72 & 0.46 & 0.76 & 0.90 & 0.87 & 8.43 & 3.90 & 0.30 & 0.72 & 107 & 17.63 \\
\hline Cluster 5 & 0.47 & 0.74 & 0.84 & 0.91 & 0.99 & 8.53 & 4.80 & 0.32 & 0.74 & 72 & 11.86 \\
\hline
\end{tabular}

Sources: Based upon data from CETESB (2011a, b, c, and d).

The presence of Guarulhos—a big city—reveals a heterogeneity within the Cluster 2. In spite of the fact of having three other major cities (Campinas, Osasco and Sorocaba), Cluster 2 still has its small municipalities representing $44 \%$ of its 39 municipalities.

Cluster 3 is the largest in number of municipalities (183). The capital of the state of São Paulo (the city of São Paulo) belongs to it. All cities that make up Cluster 3 add up to 21 million people, 11 million only in the city of São Paulo. The average population density is 402 inhabitants per $\mathrm{km}^{2}$. Despite its large population, the municipality of São Paulo is only the fifth in terms of geographical area; the most extensive municipality is Itapeva with $1826 \mathrm{~km}^{2}$. In addition to São Paulo, the Cluster 3 has four other municipalities with more than 500 thousand inhabitants (São Bernardo do Campo, Santo André, São José dos Campos and Ribeirão Preto). The smallest municipality registered in Cluster 3 is Uru with 1251 inhabitants and population density of 8.48 inhabitants per $\mathrm{km}^{2}$. The average income for the whole Cluster 3 is $\mathrm{R} \$ 667.00$. The municipality with the highest income per capita is Santana de Parnaíba (R\$ 1575.00) and the lowest is in Canitar (R\$ 432.00). The city of São Paulo has the third highest per capita income of this Cluster 3.

Cluster 4 is characterized by small and small-medium towns. Its total population is 1.3 million inhabitants and the average population density is 50 inhabitants per $\mathrm{km}^{2}$. The largest municipality in terms of population has 74,074 inhabitants (Campo Limpo Paulista).In terms of geographical area, the largest municipality is Capão Bonito $\left(1641 \mathrm{~km}^{2}\right)$ and the smallest is Holambra $\left(64 \mathrm{~km}^{2}\right)$. Despite being the smallest municipality, in extension, Holambra has the highest per capita income ( $\mathrm{R} \$ 1019.00)$. The smallest registered income is $\mathrm{R} \$ 375.00$ (Areias). The average per capita income in Cluster 4 is $\mathrm{R} \$ 565.54$.

Small municipalities characterize Cluster 5, similarly to Cluster 1 . Only 3 out of 107 municipalities have more than 50 thousand inhabitants. Its smallest municipality is Paulistânia, with 1779 inhabitants. In terms of area the largest municipality is Itaí with $1112 \mathrm{~km}^{2}$ and the smallest is Canas $\left(53 \mathrm{~km}^{2}\right)$. The average per capita income of municipalities is $\mathrm{R} \$$ 607.79. The largest recorded per capita income is $\mathrm{R} \$ 902.00$ (Santa Cruz da Conceição) and the lowest was in Canas (R\$ 409.00). The highest population density is Santa Gertrude (221.45 inhabitants per $\mathrm{km}^{2}$ ), while the smallest is in Paulistânia (6.93 inhabitants per $\mathrm{km}^{2}$ ).

From these characteristics just described for each cluster and from the information summarized in Table 1 we can observe very heterogeneous clusters both in terms of population size and density and in terms of income. As a matter of fact, with the exception of Clusters 1 and 5, clusters present great variability of cities when considered population, geographic area and income. As far as environmental quality within each cluster is concerned, one can observe that the two clusters with smaller municipalities do not have many environmental advantages for selected variables in relation to the other three clusters. Cluster 1 presents the best average of sanitary sewage treatment, the smallest number of contaminated areas and the lowest daily production of solid waste. However, Cluster 5 does not distinguish itself in any of the variables taken into consideration.

Based upon these results, we cannot arrive at a conclusive answer to the question we formulated in the beginning of this paper. Cluster analysis was not sufficient to achieve our goal. In spite of the fact that it was possible to verify that there was a clear differentiation between large and small urban agglomerations with regard to selected environmental indicators, we could not sort the clusters regarding environmental quality in order to ex- 
amine whether the presence of a large city is detrimental to the environmental performance of the cluster. In order to sort the indexes of quality for municipalities and their clusters, we constructed an indicator of socio-economic and environmental quality for each municipality using factorial analysis.

\subsection{Factorial Analysis-Municipal Quality Indicator}

The Municipal Quality Indicator (IQM) allowed us to compare the environmental quality enjoyed by residents in each of the municipalities without disregard the quality of life presented in each one of them. Factorial analysis was used for the composition of the IQM. To make use of factor analysis is necessary to ensure that selected variables are correlated, i.e., having non-zero correlation coefficient. Table 2 presents the correlation matrix when tested all variables for all 607 municipalities. Note that, despite the existence of correlation, it was very low in some cases such as, for example, between IQR and proportion of households served by running water. The fact that there are correlations of lower mounts do not preclude the application of the method for the construction of the IQM.

After checking the feasibility of application of factor analysis was necessary to define the number of factors used for construction in the IQM. Given that our objective through this approach was to reduce the number of database variables by creating a smaller number of unobservable variables. The definition of the number of factors depends on the number of variables, observations and the correlation between variables. To set this option, it was rated the degree of explanation of the Eigen values as greater than 0.7. For this study there were used 5(five) factors with an explanatory power of $81.3 \%$.

We calculated the value of IQM for each of the municipalities. However, obtained results, however, did not allow the comparison of indicators, because there were negative indexes. To carry out the comparison, IQMs were normalized, generating a new value for them. Thus the IQM ranged from zero to 100 (one hundred). The maximum (100) registers the best environmental quality considering the selected variables. Our calculation was done with the nine selected variables and we obtained 60.76 as the largest IQM.

Our result indicates that the environmental quality of the municipalities of the state of São Paulo is at least $40 \%$ smaller than the possible maximum. For the analysis of clusters of IQM was used the k-means method and to determine the number of clusters the technique employed was vfold. In this context, the cluster that had the best IQM was the number 5. The cluster that had the largest variance was the number 3 . When considered the heterogeneity among the clusters, it was observed that the greatest distance was between Clusters 5 and 3 . These were, therefore, the best and worst clusters, respectively.

Given these results, it is necessary to evaluate the composition of each cluster. Cluster 5 is formed by a single municipality: São Paulo. The result contradicts several studies that claim that larger urban agglomerations present worst environmental quality indicators. Cluster 4 is the second best ranked. It has 147 municipalities and, among them, the largest municipality in terms of population is Guarulhos. In addition to Guarulhos, other major cities are also component of the Cluster (Campinas, São Bernardo do Campo, Santo André, for example). On the other hand, the cluster that has the worst performance was the Cluster 3. Composed of 50 municipalities this cluster focuses municipalities that revealed IQM ranging from 11.53 and 18.04. Cluster 3 is formed by small and small-medium municipalities. One of its municipalities—Redenção with 3873 inhabitants—presented the worst result for the whole state of São Paulo.

The formation of the clusters after the creation of the IQM revealed that it is not possible to affirm that smaller cities have better environmental quality than large cities. However, even with the fact the two worst clusters were formed by small municipalities, we cannot say that larger urban agglomerations had better environmental quality indicators. When considered the 20 best placed municipalities in terms of IQM we observed the presence of municipalities of all sizes and with varying levels of income per capita. Our results confirms that, for the state of São Paulo in Brazil and for the selected variables, it is not possible to say, categorically, that smaller cities offer better environmental quality to its inhabitants.

It is important to emphasize that these results do not change after we tested them with a second group of variables. In this second group we did not take into consideration two variables: number of contaminated areas and production of daily garbage. These changes altered clusters and classification of cities. Nevertheless, big cities retain the best results. In this context, the result obtained in this paper differs from the consensus that compact cities are better from an environmental point of view. However, it was not enough to validate the proposal submitted by Henderson (1974) and Thisse (2010) that larger urban agglomerations generate environmental gains of scale. The only thing that can be said is that, for the state of São Paulo, the answer to the question 
Table 2. Factorial analysis: correlation matrix.

\begin{tabular}{|c|c|c|c|c|c|c|c|c|c|}
\hline & IFDM & $\begin{array}{l}\% \text { of households } \\
\text { served by } \\
\text { sanitary sewage } \\
\text { collection } \\
\text { network }\end{array}$ & $\begin{array}{l}\text { Households } \\
\text { served } \\
\text { Tap water }\end{array}$ & $\begin{array}{l}\text { Sewage } \\
\text { treatment } \\
(\%)\end{array}$ & $\begin{array}{c}\text { Number of } \\
\text { contaminated } \\
\text { areas } \\
\text { (AC-AR) }\end{array}$ & $\begin{array}{l}\text { Production } \\
\text { of Garbage } \\
\text { per day }(\mathrm{t} / \mathrm{d})\end{array}$ & $\begin{array}{l}\text { households } \\
\text { with } \\
\text { garbage } \\
\text { collected }\end{array}$ & $\begin{array}{c}\text { Prod. Per } \\
\text { capita } \\
\text { daily waste } \\
\text { (kg/hab/day) }\end{array}$ & IQR \\
\hline IFDM & 1.00000 & 0.06984 & 0.40132 & -0.11708 & 0.17951 & 0.20363 & 0.41096 & 0.31316 & 0.07906 \\
\hline $\begin{array}{l}\text { \% of households } \\
\text { served by sanitary } \\
\text { sewage network- } \\
\text { collecting }\end{array}$ & 0.06984 & 1.00000 & 0.11954 & 0.06031 & 0.06147 & 0.06314 & 0.09591 & 0.09293 & -0.02951 \\
\hline $\begin{array}{c}\text { Households } \\
\text { served tap water }\end{array}$ & 0.40132 & 0.11954 & 1.00000 & 0.01054 & 0.10164 & 0.12361 & 0.60859 & 0.39797 & -0.00477 \\
\hline $\begin{array}{c}\text { Sewage } \\
\text { treatment (\%) }\end{array}$ & -0.11708 & 0.06031 & 0.01054 & 1.00000 & -0.00969 & -0.01661 & -0.20499 & -0.00625 & -0.13160 \\
\hline $\begin{array}{c}\text { Number of } \\
\text { contaminated } \\
\text { areas (AC-AR) }\end{array}$ & 0.17951 & 0.06147 & 0.10164 & -0.00969 & 1.00000 & 0.99046 & 0.10647 & 0.10955 & 0.05114 \\
\hline $\begin{array}{l}\text { Production of } \\
\text { Garbage per } \\
\text { day }(\mathrm{t} / \mathrm{d})\end{array}$ & 0.20363 & 0.06314 & 0.12361 & -0.01661 & 0.99046 & 1.00000 & 0.12547 & 0.14553 & 0.04858 \\
\hline $\begin{array}{c}\text { Households } \\
\text { with } \\
\text { Garbage collected }\end{array}$ & 0.41096 & 0.09591 & 0.60859 & -0.20499 & 0.10647 & 0.12547 & 1.00000 & 0.33626 & 0.07337 \\
\hline $\begin{array}{l}\text { Prod. per capita } \\
\text { daily waste } \\
\text { (kg/hab/day) }\end{array}$ & 0.31316 & 0.09293 & 0.39797 & -0.00625 & 0.10955 & 0.14553 & 0.33626 & 1.00000 & 0.01998 \\
\hline IQR & 0.07906 & -0.02951 & -0.00477 & -0.13160 & 0.05114 & 0.04858 & 0.07337 & 0.01998 & 1.00000 \\
\hline Means & 0.75586 & 0.78002 & 0.85698 & 0.65824 & 5.33278 & 33.31301 & 0.92183 & 0.36301 & 8.44629 \\
\hline Std. Dev. & 0.06077 & 0.17762 & 0.11295 & 0.17168 & 46.42565 & 253.12042 & 0.06917 & 0.16648 & 1.16119 \\
\hline
\end{tabular}

that gives name to this paper is no.

\section{Conclusions}

This paper discussed the relationship between the size of urban agglomerations and environmental externalities they experience. Seminal studies on regional economy sought to understand reasons to live and to produce in urban agglomerations. Our research tries to understand reasons not to live or not to produce in (big) cities. In this context, using as an object of study municipalities of the state of São Paulo in Brazil, we sought to answer: do smaller cities have more environmental benefits than large?

To answer this question, we considered the main reasons for the formation of cities, their advantages and their disadvantages. The rationale for the existence of cities is based on two fundamental points: economies of scale and indivisibility of certain goods and services. The economy of scale issue is related to gains from the reduction of the marginal costs of production and the formation of large consumer market and of concentration of manpower-supply. The indivisibility issue is closely related to public services such as electricity supply, water treatment, sanitation infrastructure, hospitals and health care, etc. For all these services, sunk costs in their provision are very high, requiring a range of significant consumption in order to make their supply feasible.

Despite all these benefits, cities have a number of negative externalities. These externalities shall be considered in any economic analysis assessing social welfare of urban inhabitants. Congestion, water, air and soil pollution, violence and crime, among others, are factors that must be considered when conducted a cost-benefit analysis of whether to live or to install in urban agglomerations. As we shown, the vast majority of scholars agree with the fact that inasmuch cities grow the negative effects of agglomeration grow more rapidly that the gains arise from urbanization. The mismatch between the private and social cost curves would be the reason for the existence of cities with size larger than its optimal size. The failure in internalize some costs of urbanization would be responsible for the disorderly growth of cities. 
However, in looking at the reality of developing country urban areas, we arrive at a result different from that of a large portion of studies. Our results were more in line to those by Henderson (1974). His result was that, with a new allocation of income and better quality of life quality, the big city would become attractive to new residents. Largely Henderson's result was because in larger cities income tends to be higher. The higher remuneration of agents enables them to demand new goods, including luxury goods like the environment. The greatest willingness and ability to pay and the new basket of consumption of residents in big cities drives the demand for goods such as clean air, water treatment, and environmental preservation areas.

Motivated by the paper by Thisse (2011) our paper tested the hypothesis that the most efficient structure for environmental preservation and social welfare would exist in large cities. Our investigation was conducted using multivariate analysis. This choice was due to the fact this approach allows the use of several variables and is quite useful in decision-making for public and private managers. We, in fact, structured clusters able to combine cities with similar indicators enabling a comparison between cities of environmental indicators and indicators of the quality of life enjoyed by residents.

Our results indicate that, for the state of São Paulo, it is not possible to affirm that smaller cities provide better environmental quality to their population. It was also possible to verify that largest cities and those with higher income are able to provide to its inhabitants better conditions of sanitation, water treatment and garbage collection. This confirms the hypothesis that the scale of cities makes the provision of the so-called indivisible services, including services related to good environmental management. The complexity of the matter recommends further studies on the topic and the consideration of other variables not covered here. However, this research has helped to reinforce the need to study the relationship between land use and occupation and their environmental impacts, as well as to quantify this relationship.

\section{References}

Albuquerque, M. A. (2005). Estabilidade em análise de agrupamento (cluster analysis). Dissertação apresentada à Universidade Federal Rural de Pernambuco. Pernambuco.

Au, C.-C., \& Henderson, J. V. (2006). Are Chinese Cities Too Small? Review of Economic Studies, 73, 549-576. http://dx.doi.org/10.1111/j.1467-937X.2006.00387.x

Banco Mundial (1992). Relatório sobre o Desenvolvimento Mundial 1992: Desenvolvimento e meio ambiente (1st ed.), Rio de Janeiro: Imprinta.

Banco Mundial (2009a). Cidades Verdes: Cidades e Mudanças Climáticas no Brasil: Resultados Preliminares. http://siteresources.worldbank.org/BRAZILINPOREXTN/Resources/3817166-1279658706544/Lynch_CidadesMundanc asClimaticas.pdf

Banco Mundial (2009b). Relatório sobre o Desenvolvimento Mundial 2009: A Geografia Econômica em Transformação. São Paulo: Editora Singular for the World Bank..

Banister, D. (1999). Urban Sustainability. Chapter 38. In J. C. J. M. van den Bergh (Ed.), Handbook of Environmental and Resource Economics (pp. 560-568), UK and USA: Edward Elgar.

CETESB (2011a). Áreas contaminadas 2011. http://www.cetesb.sp.gov.br/areas-contaminadas/rela\%E7\%F5es-de-\%E1\%A1reas-contaminadas/4-rac

CETESB (2011b). Inventário estadual de resíduos sólidos domiciliares 2010. São Paulo: CETESB,

CETESB (2011c).Qualidade das águas subterrâneas no estado de São Paulo 2007-2009. São Paulo: CETESB,

CETESB (2011d).Qualidade do ar no estado de São Paulo 2010/ CETESB. São Paulo: CETESB,

Cluster Analysis, Capítulo 23. Autor não identificado.

http://www.uk.sagepub.com/burns/website\%20material/Chapter\%2023\%20\%20Cluster\%20Analysis.pdf

Fujita, M., \& Thisse, J. F. (1996). Economics of Agglomeration. Journal of the Japanese and International Economies, 10, 339-378. http://dx.doi.org/10.1006/jiie.1996.0021

Fujita, M., \& Thisse, J. F. (2002). Economics of Agglomeration: Cities, Industrial Location, and Regional Growth. Cambridge: Cambridge University Press. http://dx.doi.org/10.1017/CBO9780511805660

Gaigné, C., Riou, S., \& Thisse, J. F. (2011). Are Compact Cities Environmentally Friendly? CEPR Discussion Papers 8297, C.E.P.R. Discussion Papers.

Glaeser, E. L. (2007). The Economics Approach to Cities. NBER Working Papers 13696, National Bureau of Economic Research, Inc.

Glaeser, E. L., \& Gyourko, J. (2007). Arbitrage in Housing Markets. NBER Working Papers 13704, National Bureau of 
Economic Research, Inc.

Glaeser, E. L., Gyourko, J., \& Saks, R. E. (2005). Why Have Housing Prices Gone up? American Economic Association, American Economic Review, 95, 329-333. http://dx.doi.org/10.1257/000282805774669961

Governo do Estado de São Paulo (2012). http://www.saopaulo.sp.gov.br/

Henderson, J. V. (1972). Optimum City Size: The External Diseconomy Question. Working Papers 91, Kingston: Queen’s University, Department of Economics.

Henderson, J. V. (1974). Sizes and Types of Cities. American Economic Review, 64, 640-656.

Himanen, V., Perrels, A., \& Lee-Gosselin, M. (Eds.) (2005). Sustainability and the Interactions between External Effects of Transport. A Special Issue Section, Journal of Transport Geography, 1, 23-28.

Hotelling, H. (1929). Stability in Competition. Economic Journal, 39, 41-57. http://dx.doi.org/10.2307/2224214

IBGE-Instituto Brasileiro de Geografia e Estatística (2012). Estados. http://www.ibge.gov.br/estadosat/perfil.php?sigla=sp

Lampard, E. E. (1955). The History of Cities in the Economically Advanced Areas. Economic Development and Cultural Change, 3, 81-136. http://dx.doi.org/10.1086/449680

Linn, J. F. (1982). The Costs of Urbanization in Developing Countries. Economic Development and Cultural Change, 30, 625-648. http://dx.doi.org/10.1086/452578

Malhotra, N. K. (2006). Pesquisa de marketing: Uma orientação aplicada. Porto Alegre: Bookman Publisher.

Nijkamp, P. (1999). Environment and Regional Economics. In: J. C. J. M. van den Bergh (Ed.), Handbook of Environmental Economics (Capítulo 35). Reino Unido e Estados Unidos: Edward Elgar.

Rosenthal, S. S., \& Strange, W. C. (2001). The Determinants of Agglomeration. Journal of Urban Economics, 50, $191-229$.

Rosenthal, S. S., \& Strange, W. C. (2004). Geography, Industrial Organization, and Agglomeration. MIT Press, The Review of Economics and Statistics, 85, 377-393. http://dx.doi.org/10.1162/003465303765299882

Thisse, F. (2002). Handbook of Regional and Urban Economics: Cities, Industrial Location and Geography. Edited by Henderson and Thisse, Cambridge: Cambridge University Press.

Thisse, J. F. (2011). Geografia econômica. In Economia Regional e Urbana: Teorias e métodos com ênfase no Brasil. Organizadores: Bruno de Oliveira Cruz ... [et al.]. Brasília: IPEA.

UN-Habitat (2005). United Nations Human Settlements Programme. Anual Report, 2005. Nairobi.

Verhoef, E. T., \& Nijkamp, P. (2003). Externalities in the Urban Economy. Tinbergen Institute Discussion Papers 03-078/3, Tinbergen Institute.

Vincini, L. (2005). Análise multivariada: da teoria à prática. Santa Maria: Monografia de Especialização. Universidade Federal de Santa Maria - RS, Brazil.

Wheeler, C. H. (2002). Evidence on Agglomeration Economies, Diseconomies, and Growth. Journal of Applied Econometrics, 18, 79-104. 
Scientific Research Publishing (SCIRP) is one of the largest Open Access journal publishers. It is currently publishing more than 200 open access, online, peer-reviewed journals covering a wide range of academic disciplines. SCIRP serves the worldwide academic communities and contributes to the progress and application of science with its publication.

Other selected journals from SCIRP are listed as below. Submit your manuscript to us via either submit@scirp.org or Online Submission Portal.
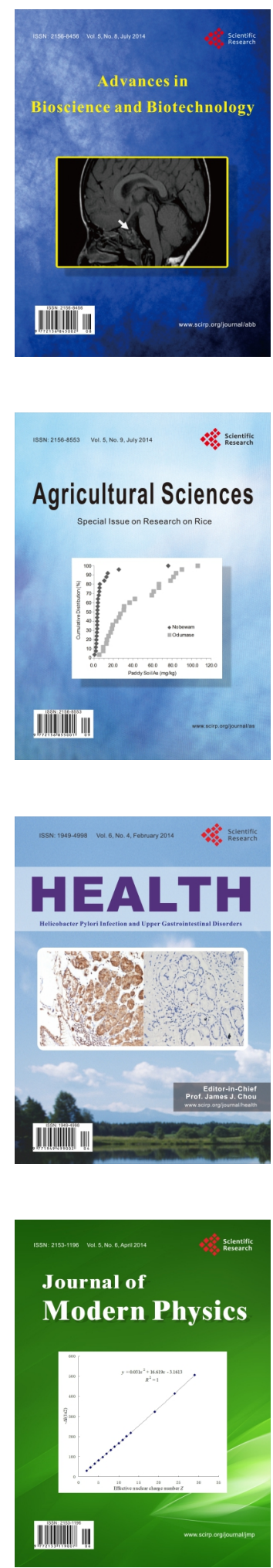
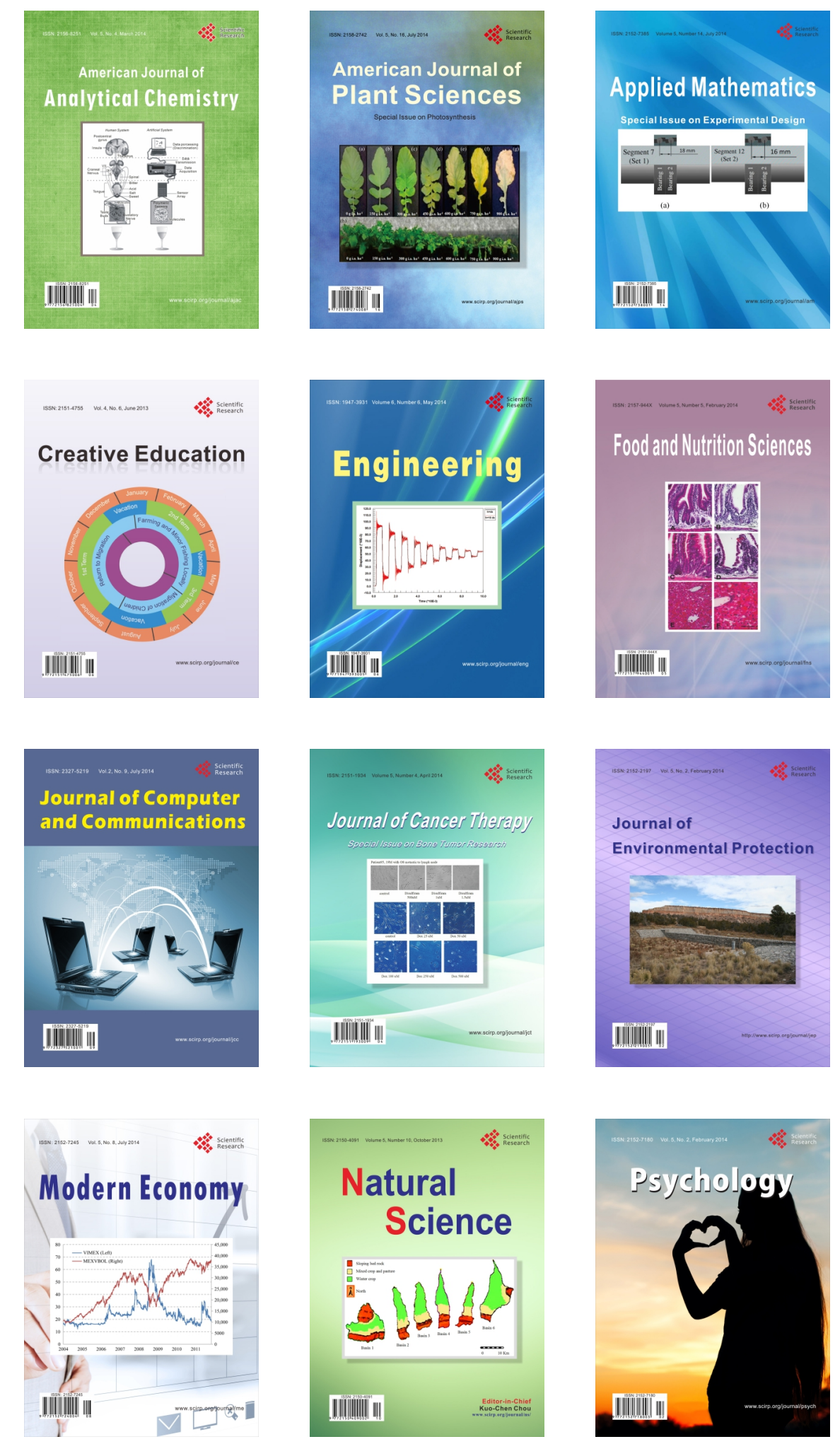